\title{
The iron- and cAMP-regulated gene SIT1 influences ferrioxamine $B$ utilization, melanization and cell wall structure in Cryptococcus neoformans
}

\author{
Kristin L. Tangen, Won Hee Jung, Anita P. Sham, Tianshun Lian \\ and James W. Kronstad
}

Correspondence James W. Kronstad kronstad@msl.ubc.ca

Received 4 August 2006

Revised 3 October 2006

Accepted 4 October 2006 Michael Smith Laboratories, Department of Microbiology and Immunology, and Faculty of Land
and Food Systems, University of British Columbia, Vancouver BC V6T 1Z4, Canada

\section{INTRODUCTION}

Cryptococcus neoformans is the leading cause of fungal meningitis in immunocompromised individuals (Casadevall \& Perfect, 1998). Five serotypes (A, B, C, D and $\mathrm{AD})$ are recognized, based on the antigenicity of the polysaccharide capsule, and three varieties have been described: neoformans (D), grubii (A) and gattii (B and C). Several virulence factors have been identified for the fungus, including the polysaccharide capsule, production of melanin by the enzyme laccase, the ability to grow at $37^{\circ} \mathrm{C}$, and survival within macrophages (Casadevall \& Perfect, 1998). The polysaccharide capsule is antiphagocytic and suppresses the immune response, while the expression of laccase and melanin formation are necessary for survival within alveolar macrophages, resistance to oxidative stress, and extrapulmonary dissemination to the brain (Bose et al., 2003; Casadevall \& Perfect, 1998; Gomez \&

\footnotetext{
Abbreviations: FOB, ferrioxamine B; LIM, low-iron medium; NAT, nourseothricin; PKA, protein kinase A; SAGE, serial analysis of gene expression; TEM, transmission electron microscopy; wt, wild-type.

A list of primers used in the study, and an amino acid alignment of the Sit1 protein from the serotype D strain B3501A of C. neoformans with fungal orthologues, are available as supplementary data with the online version of this paper.
}

Nosanchuk, 2003; Janbon, 2004; Liu et al., 1999; Noverr et al., 2004; Perfect, 2005; Williamson, 1997). Capsule and melanin production are regulated by several factors. For example, capsule size is influenced by iron and $\mathrm{CO}_{2}$ levels, serum, and the location of the fungus in host tissue (Bose et al., 2003; Janbon, 2004; Vartivarian et al., 1993; Zaragoza et al., 2003). Melanin synthesis is regulated by iron and copper, and by low glucose levels (Alspaugh et al., 1997; Jacobson \& Compton, 1996; Polacheck et al., 1982; Salas et al., 1996; Zhu et al., 2001; Zhu \& Williamson, 2004). The cAMP pathway is known to regulate both capsule and melanin, and the PKC1/MAP kinase pathway has also been implicated in melanin production, because loss of the $\mathrm{C} 1$ domain of $P K C 1$ leads to reduced laccase activity (Alspaugh et al., 1997; D’Souza et al., 2001; Heung et al., 2005; Hicks et al., 2004).

We are interested in the mechanisms of iron regulation and uptake in C. neoformans. Physiological and genetic studies indicate that iron acquisition is mediated by both high- and low-affinity uptake systems, with a role for cell surface ferric reductase activity, secreted reductants such as 3-hydroxyanthranilic acid, and melanin (Jacobson et al., 1998; Lian et al., 2005; Nyhus et al., 1997; Nyhus \& Jacobson, 1999). Based on similarities with Saccharomyces cerevisiae (Stearman et al., 1996), the high-affinity uptake system is 
believed to be composed of an iron permease, Ftr1, and a multicopper oxidase, Fet3, and iron regulation of these components has been confirmed by transcriptome analysis (Lian et al., 2005). Iron uptake is also potentially mediated by siderophores that are exported from cells to bind ferric iron, with subsequent import. This strategy is common for both fungi and bacteria, and siderophores may allow pathogens to steal iron from host proteins such as transferrin or ferritin, or from nutritional competitors in their environment (Barasch \& Mori, 2004; Haas, 2003). However, Jacobson \& Petro (1987) were unable to identify extracellular iron chelators and hydroxamate-type siderophores in C. neoformans, although they did demonstrate that the fungus can use the siderophore deferoxamine in the presence of $\mathrm{FeCl}_{3}$.

Specific transporters are required for non-reductive uptake of ferric-siderophore complexes. Interestingly, some fungi, such as the pathogen Candida albicans and S. cerevisiae, have homologues for siderophore transporters, even though they apparently do not possess the enzymes for the synthesis of siderophores (reviewed by Haas, 2003). It is presumed that the transporters allow these fungi to utilize siderophores from competitors. In S. cerevisiae, there are four siderophore transporters: ARN1, ARN2/TAF1, ARN3/SIT1 and ARN4 (Lesuisse et al., 2001; Haas, 2003; Yun et al., 2000a, b). The specificity of some of these transporters has been examined and, although issues of redundancy exist, Arn $3 p / S i t 1 p$ has high affinity for the hydroxamate siderophore ferrioxamine B (FOB; feroxamine), and lesser affinity for ferrichromes and ferricrocin (Kosman, 2003; Lesuisse et al., 2001; Yun et al., 2000a, b). C. albicans contains a similar set of transporters to those found in S. cerevisiae, and one of these, CaArn1/CaSit1, is required for epithelial cell invasion but not for systemic infection (Ardon et al., 2001; Haas, 2003; Heymann et al., 2002; Hu et al., 2002; Kosman, 2003). Aspergillus fumigatus is also thought to have siderophore transporters, and the loss of ability to synthesize siderophores compromises virulence in this fungus (Haas, 2003; Hissen et al., 2005; Schrettl et al., 2004). Recently, we have identified the transcript for a putative siderophore transporter (SIT1) by serial analysis of gene expression (SAGE) in C. neoformans, and have found that the message is elevated in cells grown in low-iron medium (LIM) (Lian et al., 2005). This discovery suggests that $C$. neoformans may be able to utilize siderophores via a specific transporter or receptor, as predicted by Jacobson \& Petro (1987).

In this study, we constructed null mutants for SIT1 in the serotype D strain B3501A and the serotype A strain H99 of C. neoformans, and established that the gene is required by both strains for siderophore (FOB) utilization and growth in a low-iron environment. We also found that SIT1 influences melanization and cell wall structure, and that this role is more pronounced in the serotype D strain B3501A. As has been observed in other studies (Barchiesi et al., 2005; Hicks et al., 2004), our analysis revealed differences in sit1 phenotypes for the strains of the A and D serotypes. We also extended our studies to show that the cAMP pathway influences SIT1 transcript levels. Finally, we found that SIT1 is not required for virulence in a mouse model of cryptococcosis.

\section{METHODS}

Strains and growth conditions. The strains used in this study are listed in Table 1. Strain B3501A was provided by Dr J. Kwon-Chung (National Institutes of Health, Bethesda. MD). Strains JEC21, JEC43 and H99, and all of the mutants with defects in cAMP signalling components, were provided by Dr J. Heitman (Duke University, Durham, NC). The ura5 mutant of B3501A was isolated by selection on 5-fluoroorotic acid plates. LIM was prepared with 20mM HEPES and $20 \mathrm{mM} \mathrm{NaHCO}$, as described by Vartivarian et al. (1993). The water for LIM was treated with Chelex-100 resin (Bio-Rad) to chelate iron. LIM + Fe was prepared by addition of $100 \mu \mathrm{M} \mathrm{Fe}^{3+} / \mathrm{EDTA}$ (Sigma catalogue ref. EDFS). LIM + bathophenanthroline disulfonic acid (BPDA) + deferoxamine was prepared by addition of $550 \mu \mathrm{M}$

Table 1. C. neoformans strains used in this study

\begin{tabular}{|c|c|c|c|c|}
\hline Strain & Genotype & Serotype & Strain background & Source \\
\hline B3501A & MAT $\alpha$ wt & $\mathrm{D}$ & NA & J. Kwon-Chung \\
\hline b-ul & $\operatorname{MAT} \alpha \operatorname{ura5}\left(\mathrm{FOA}^{\mathrm{R}}\right)$ & $\mathrm{D}$ & B3501A & This study \\
\hline b-s42 & MAT $\alpha \Delta s i t 1:: U R A 5$ ura5 & $\mathrm{D}$ & B3501A & This study \\
\hline b-s42R1 & MAT $\alpha \Delta$ sit1:: URA5 ura5+SIT1::NAT & $\mathrm{D}$ & B3501A & This study \\
\hline h-s1 & MAT $\alpha \Delta$ sit1::NEO & A & H99 & This study \\
\hline h-s2 & MAT $\alpha \Delta s i t 1:: N E O$ & A & H99 & This study \\
\hline h-s1R1 & MAT $\alpha \Delta$ sit1::NEO+SIT1::NAT & A & H99 & This study \\
\hline $\operatorname{cdc} 40$ & MAT $\alpha$ pka1::ADE2 ade2 & $\mathrm{D}$ & JEC21 & J. Heitman \\
\hline cdc 99 & MAT $\alpha$ pka2:: URA5 ura5 & $\mathrm{D}$ & JEC21 & J. Heitman \\
\hline
\end{tabular}


BPDA (Sigma) and $100 \mu \mathrm{M}$ deferoxamine (deferrioxamine; Sigma). To measure growth in liquid media, $5 \mathrm{ml}$ yeast extract peptone dextrose (YPD) medium was inoculated with a single colony, and grown overnight at $30^{\circ} \mathrm{C}$ in a gyratory shaker at 250 r.p.m. One hundred microlitres of culture was transferred to $5 \mathrm{ml}$ yeast nitrogen base medium, and grown overnight at $30^{\circ} \mathrm{C}$. Cells were washed four times with sterile water, and transferred to flasks containing $50 \mathrm{ml}$ $\mathrm{LIM}, \mathrm{LIM}+\mathrm{Fe}$ or LIM + BPDA + deferoxamine at a concentration of $1 \times 10^{6}$ cells $\mathrm{ml}^{-}$. The cultures were shaken at 250 r.p.m. at $30^{\circ} \mathrm{C}$, and growth was monitored by measuring $\mathrm{OD}_{600}$ on a Beckman DU530 UV/VIS spectrophotometer with a $1 \mathrm{~cm}$ path length.

Identification of SIT1 and siderophore transporter orthologues. SIT1 and additional candidate siderophore transporter orthologues were identified by using the sequences of the characterized $S$. cerevisiae siderophore transporters (Lesuisse et al., 2001; Yun et al., $2000 \mathrm{a}, \mathrm{b})$ to search the $C$. neoformans genome sequence databases for strains JEC21 (http://www.tigr.org/tdb/e2k1/cnal/), B3501A (http://www-sequence.stanford.edu/group/C.neoformans/index.html) and H99 (http://cneo.genetics.duke.edu). The gene identifications assigned to SIT1 in JEC21 and H99 are CNA07920 and GLEAN05672, respectively. Transmembrane regions for the Sit1 sequence were predicted using TMHMM (http://www.cbs.dtu.dk/ services/TMHMM).

RNA isolation and analysis. Cells were grown in LIM and $\mathrm{LIM}+\mathrm{Fe}$, as described above, harvested by centrifugation, flashfrozen in a dry ice/ethanol bath, and lyophilized overnight at $-20^{\circ} \mathrm{C}$. Cell pellets were pulverized with glass beads for $10 \mathrm{~min}$, and the cell powder was resuspended in $15 \mathrm{ml}$ Trizol extraction buffer (Invitrogen). RNA was isolated according to the manufacturer's recommendations, with the additional step of $\mathrm{LiCl}$ precipitation at $4{ }^{\circ} \mathrm{C}$ after ethanol precipitation. Northern blot preparation and hybridization were performed as described by Sambrook et al. (1989), and all hybridization experiments were performed with two independent preparations of RNA from cells grown in LIM or $\mathrm{LIM}+\mathrm{Fe}$. The hybridization probe was a PCR-amplified $409 \mathrm{bp}$ DNA fragment from exon 6 of the SIT1 gene, using primers SITEXON6F and SITEXON6R (all primer sequences are listed in Supplementary Table S1). The probe was labelled with ${ }^{32} \mathrm{P}$ using an oligolabelling kit (Amersham Pharmacia Biotech).

Primers for real-time RT-PCR analysis were designed for each serotype using Primer Express software 3.0 (Applied Biosystems) (Supplementary Table S1). Cell cultures were prepared as described below for the laccase assay. Total RNA was purified with the RNeasy kit (Qiagen), treated with DNase (Qiagen), and cDNA was generated using the SuperScript First-Strand Synthesis system (Invitrogen). PCR reactions contained $750 \mathrm{nM}$ of each primer, $1 \times$ Power SYBR Green PCR Master Mix (Applied Biosystems) and $100 \mathrm{ng}$ cDNA in a final volume of $20 \mu \mathrm{l}$. PCR reactions were performed on the Applied Biosystems 7500 Fast Real-Time PCR system, with $50{ }^{\circ} \mathrm{C}$ incubation for $2 \mathrm{~min}, 95^{\circ} \mathrm{C}$ for $10 \mathrm{~min}$, followed by 40 cycles of $95^{\circ} \mathrm{C}$ for $15 \mathrm{~s}$ and $60^{\circ} \mathrm{C}$ for $1 \mathrm{~min}$. Relative gene expression was quantified using the SDS software 1.3.1 (Applied Biosystems), based on the $2^{-\Delta \Delta \mathrm{CT}}$ method (Livak \& Schmittgen, 2001), and ACT1 was used as an endogenous control for normalization.

Construction of sit1::URA5 (serotype D) and sit1:: NEO (serotype A) alleles. A PCR overlap strategy was used to prepare a deletion allele for strain B3501A (Davidson et al., 2002). DNA fragments containing the $5^{\prime}\left(742 \mathrm{bp}\right.$ ) and $3^{\prime}$ (853 bp) regions flanking the SIT1 gene were amplified from genomic DNA from strain JEC21. Note that JEC21 and B3501A are closely related strains (Loftus et al., 2005). The primers adjacent to the $5^{\prime}$ and $3^{\prime}$ regions of the gene were SIT1A and SIT1C, and SIT1D and SIT1F, respectively. The URA5 marker was amplified from plasmid pJHM973 using hybrid primers SIT1B and SIT1E for SIT1 and URA5, respectively.
The three fragments were joined by overlapping PCR (Davidson et al., 2002) using primers SIT1A and SIT1F. For strain H99, a modified overlap strategy was employed that increased the yield of the final construct (Yu et al., 2004). DNA fragments containing the $5^{\prime}$ (1151 bp) and $3^{\prime}$ (1162 bp) regions flanking the SIT1 gene were amplified from genomic DNA of H99. The primers adjacent to the $5^{\prime}$ and $3^{\prime}$ regions of the gene were SITA1 and SITA3, and SITA4 and SITA6, respectively. The neomycin cassette was amplified from pJAF1 using hybrid primers SITA2 and SITA5 for SIT1 and NEO, respectively. Fragments were used in second- and third-round PCR reactions, as described by $\mathrm{Yu}$ et al., 2004. The nested primers used in the third round of PCRs were SITANF and SITANR. The DNA constructs were introduced into the appropriate parent strains by biolistic transformation (Toffaletti et al., 1993). Transformants were screened by colony PCR using primers SIT1UP and 6328 for strain B3501A, and SITAUP and NEOPS for strain H99. Transformants in which the wild-type (wt) allele was replaced were confirmed by Southern analysis using the $5^{\prime}$ fragment (generated with primers SIT1A and SIT1C) as a probe; the absence of SIT1 transcripts in the mutants was confirmed by quantitative real-time PCR. Two mutants for each strain were retained for analysis. To complement the mutations, the wt SIT1 gene was reintroduced by biolistic transformation into one mutant of each strain background, on the vector pCH233 that confers resistance to nourseothricin (NAT).

Plate assays. Siderophore utilization assays were performed as described by Heymann et al. (2002). Plates of ferrous-iron-free medium (IFM) were prepared in the same manner as for LIM, with the addition of $20 \mathrm{~g}$ Bacto-agar $1^{-1}$ and $550 \mu \mathrm{M}$ BPDA chelator. Two hundred microlitres of cell suspension containing $10^{7}$ c.f.u. $\mathrm{ml}^{-1}$ were spread on IFM, and a disk of Whatman paper saturated with $10 \mu \mathrm{l} 100 \mu \mathrm{M}$ deferoxamine or ferrichrome (Sigma) was placed in the centre of the plate. Plates were incubated for 2 days at $30^{\circ} \mathrm{C}$, and zones of growth were recorded by digital photography. Melanin assays were performed on 3,4-dihydroxyphenylalanine (DOPA; Sigma) medium that was prepared with $20 \mathrm{~g}$ Bacto agar $\mathrm{l}^{-1}$ in $900 \mathrm{ml}$ distilled water. Separately, $1 \mathrm{~g} \mathrm{~L}$-asparagine (Sigma), 1 g glucose, $3 \mathrm{~g} \mathrm{KH}_{2} \mathrm{PO}_{4}, 0.25 \mathrm{~g} \mathrm{MgSO}_{4} .7 \mathrm{H}_{2} \mathrm{O}$ and $200 \mathrm{mg}$ DOPA were dissolved in $100 \mathrm{ml}$ distilled $\mathrm{H}_{2} \mathrm{O}$ and the $\mathrm{pH}$ was adjusted to 5.6. One milligram of thiamine/ $\mathrm{HCl}$ (Sigma) and $5 \mu \mathrm{g}$ biotin (Sigma) were added, the mixture was filter-sterilized, and then added to the autoclaved agar after cooling to $50^{\circ} \mathrm{C}$. The following modifications were made to DOPA medium prior to filter-sterilization to test various parameters: $4 \times$ DOPA contained $4 \mathrm{mM}$ instead of $1 \mathrm{mM}$ DOPA (Sigma), and $4 \times$ DOPA + glucose contained $4 \mathrm{mM}$ DOPA and $1.0 \%$ glucose (instead of $0.1 \%$ ). To test for melanin production, $10 \mu 10^{7}$ c.f.u. $\mathrm{ml}^{-1}$ cell suspension was spotted on the plates and pigment was assessed after 2 days incubation at $30^{\circ} \mathrm{C}$. Temperature sensitivity assays were performed on low-glucose asparagine (LGA) medium and on DOPA medium. Tenfold serial dilutions of cells $(5 \mu \mathrm{l})$ were spotted on either LGA or DOPA plates, with an initial inoculum of $10^{7}$ c.f.u. $\mathrm{ml}^{-1}$. Plates were incubated for 2 days at 30 or $37^{\circ} \mathrm{C}$. Cell wall integrity assays were performed as above, except that $0.015 \%$ SDS, $300 \mu \mathrm{g}$ Congo red ml ${ }^{-1}$ or $30 \mu \mathrm{g}$ calcofluor white $\mathrm{ml}^{-1}$ was added to the medium. All experiments were repeated at least three times.

Laccase assays. Laccase assays were performed by inoculating $50 \mathrm{ml}$ LGA (asparagine medium with $0.1 \%$ glucose) with a single colony and growing the cells for 2 days at $30^{\circ} \mathrm{C}$. Cells were washed three times with $50 \mathrm{ml}$ sterile deionized water, resuspended in $50 \mathrm{ml}$ asparagine medium with no glucose, and grown for $4 \mathrm{~h}$ at $30^{\circ} \mathrm{C}$. In experiments to examine the effect of metal availability on laccase activity or LAC1 transcript levels, $100 \mu \mathrm{M} \mathrm{CuSO}_{4}$ or $100 \mu \mathrm{M} \mathrm{Fe}^{3+}$ / EDTA was included during the $4 \mathrm{~h}$ incubation. Cells were pelleted and washed three times with $50 \mathrm{ml} 0.05 \mathrm{M} \mathrm{NaPO}_{4}$ and resuspended at $10^{8}$ c.f.u. $\mathrm{ml}^{-1}$. To measure activity, $10^{8}(1 \mathrm{ml})$ cells were incubated 
with $1 \mathrm{mM}$ DOPA for $30 \mathrm{~min}$ at $30^{\circ} \mathrm{C}$, the cells were pelleted, and $A_{475}$ of the supernatant was recorded $\left(A_{475} 0.001\right.$ corresponds to $1 \mathrm{U}$ laccase). The laccase assays were repeated three times.

Microscopy. Transmission electron microscopy (TEM) was performed on a Hitachi H7600 microscope. The cells were grown, as described for the DOPA plate assays, on DOPA or LGA medium for 4 days at $30^{\circ} \mathrm{C}$. The full $10 \mu \mathrm{l}$ spot of cell growth from DOPA or LGA medium was resuspended in $1 \mathrm{ml}$ water, vortexed for $10 \mathrm{~min}$, and then centrifuged for $5 \mathrm{~min}$ at 13200 r.p.m. Cells were fixed in $2.5 \%$ glutaraldehyde in $0.05 \mathrm{M}$ cacodylate buffer at $28{ }^{\circ} \mathrm{C}$ under vacuum. Microwave (Ted Pella Microwave) processing was employed at $100 \mathrm{~W}$, with $2 \mathrm{~min}$ on and $2 \mathrm{~min}$ off (repeated twice). Samples were washed twice with cacodylate buffer at $28{ }^{\circ} \mathrm{C}$ for $40 \mathrm{~s}$, using power level 2. Cells were fixed in osmium tetroxide at $28^{\circ} \mathrm{C}$ under vacuum, by microwave processing at $100 \mathrm{~W}, 2 \mathrm{~min}$ on and 2 min off (repeated twice). Samples were dehydrated in increasing concentrations of 50,70, 90 and $100 \%$ ethanol (the final step was repeated three times). Samples were infiltrated with Spurrs resin in increasing ratios of Spurrs:acetone, $1: 3,1: 1$ and $3: 1$, at vacuum power level 3 for $3 \mathrm{~min}$. Resin was polymerized by baking the sample overnight at $60^{\circ} \mathrm{C}$. Samples were then cut into $70 \mathrm{~nm}$ sections on a Leica Ultracut T Ultramicrotome, and stained with $2 \%$ uranyl acetate for $14 \mathrm{~min}$ and lead citrate for $7 \mathrm{~min}$.

Virulence assays. Cells were prepared by inoculating $5 \mathrm{ml}$ YPD with a single isolated colony, followed by overnight growth on a gyratory shaker $\left(250\right.$ r.p.m) at $30^{\circ} \mathrm{C}$. Cells were washed three times with sterile PBS and resuspended in $5 \mathrm{ml}$ PBS. Cells were counted with a haemocytometer, and counts were confirmed by plating serial dilutions of strains on YPD agar, with subsequent growth for 2 days at $30^{\circ} \mathrm{C}$ to determine c.f.u. The serotype D strain B3501A and the corresponding sit1 mutant were tested initially using DBA1 mice (16-20 g; Jackson Laboratories) with a defect in C3 complement. Five mice were used for wt B3501A, and four mice were inoculated with the sit 1 mutant. The mice were inoculated by intranasal inhalation of $5 \times 10^{6}$ cells in $50 \mu \mathrm{l}$ PBS per mouse. For serotype A, A/Jcr mice (16-20 g; NIH Program) were infected intranasally with an inoculum of $5 \times 10^{4}$ fungal cells in $50 \mu \mathrm{l}$ PBS per mouse. Ten mice were used for each of the wt, sit 1 and sit1 + SIT1 strains. An additional experiment was performed using a 10 -fold smaller inoculum of $5 \times 10^{3}$ cells in $50 \mu \mathrm{l}$ PBS, and five mice per strain. Animals that appeared moribund or in pain were euthanized.

\section{RESULTS}

\section{Characterization of the SIT1 gene}

The SIT1 gene was originally identified during the analysis of SAGE data for the serotype D strain B3501A, and was found to have a 3.3-fold higher transcript level in cells grown in LIM compared with LIM + Fe (Lian et al., 2005). Examination of the gene indicated that it contained five introns and six exons, and encoded a predicted polypeptide of 604 aa with 13 putative transmembrane regions. We compared Sit 1 to related sequences in other fungi and found that the closest orthologue, Arn3/Sit1 of S. cerevisiae, showed $39 \%$ identity and $55 \%$ similarity, resulting in an e value of $10^{-112}$ using the BLASTP algorithm (Altschul et al., 1990). SIT1 was also the best match with two of the three other siderophore transporter genes (ARN1 and $A R N 2)$ of $S$. cerevisiae. This was true in searches of all three $C$. neoformans genomes (strains JEC21, B3501A and H99), although we did identify three other candidates for siderophore transporter genes in each genome. Alignments of the Sit1 amino acid sequence with Arn3/Sit1 and orthologues from other fungi are presented in Supplementary Fig. S1. To begin a functional analysis of SIT1, we used RNA blot analysis to confirm that the transcript was elevated in cells from LIM in strains B3501A and H99 (serotype A) (Fig. 1).

\section{SIT1 is required for iron acquisition under iron- limited conditions}

To investigate the role of the SIT1 gene in iron acquisition, null mutants were constructed in strains B3501A and H99. The entire coding region was deleted with transformation cassettes constructed by overlap PCR with a URA5 marker for strain B3501A and a neomycin marker for H99 (Fig. 2) (Davidson et al., 2002; Varma et al., 1992; Yu et al., 2004; Methods). Two independent transformants were obtained and characterized for both B3501A and H99. Replacement of the wt allele by the appropriate marker in the mutants was confirmed by colony PCR and Southern analysis (Fig. 2). The sit 1 mutants were reconstituted by transformation with the wt SIT1 gene from strain JEC21 cloned into a vector containing an NAT-resistance gene.

Growth assays were initially performed on iron-free solid medium supplemented with deferoxamine to examine siderophore utilization in the sit1 mutants. This medium contains the ferrous iron chelator BPDA (Cowart et al., 1993) to establish conditions in which the cells must use ferric iron sequestered from the medium by deferoxamine. Under these conditions, zones of growth were apparent for all wt and reconstituted strains, but not for any of the sit1 mutants at 2 or 7 days (Fig. 3). These assays indicate that the sit1 mutants were unable to use FOB as a sole source of iron. In S. cerevisiae, Arn3/Sit 1 can mediate the uptake of FOB or ferrichrome (Lesuisse et al., 1998; Yun et al., 2000a, b). We therefore tested our strains in the same plate assays with ferrichrome in place of deferoxamine, and we observed growth for all of the strains (data not shown). This result

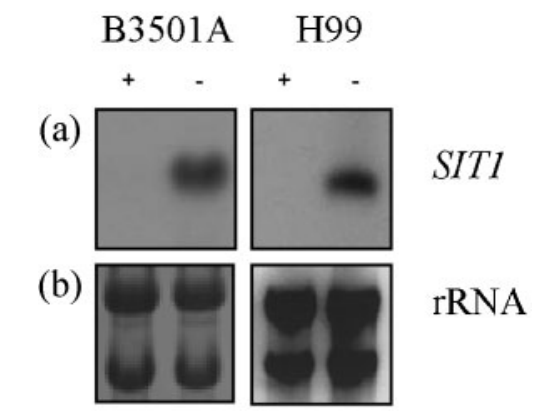

Fig. 1. Iron regulation of SIT1 transcript levels. A Northern blot was prepared with total RNA isolated from cells grown in LIM $(-)$ or iron-replete medium (+) at $37^{\circ} \mathrm{C}$ for $6 \mathrm{~h}$. Blots were hybridized with a DNA fragment from exon 6 of the SIT1 gene of strain JEC21. (a) SIT1 transcript levels; (b) rRNA (18S and 28S) bands as a loading control. 
(a)


(c)

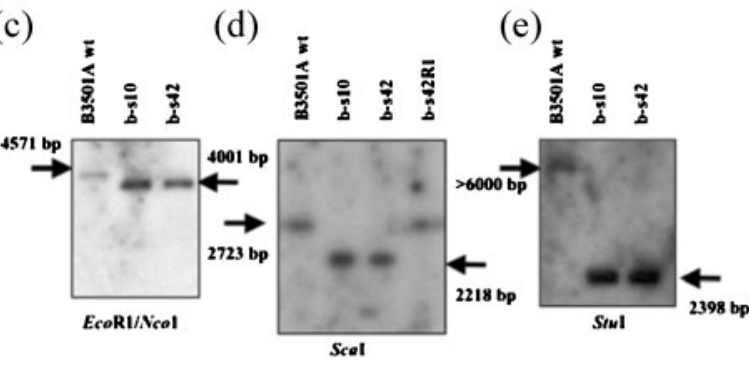

(f)

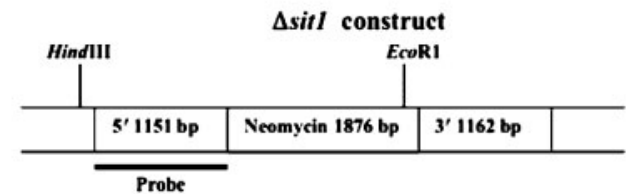

SITI genomic sequence

(g)

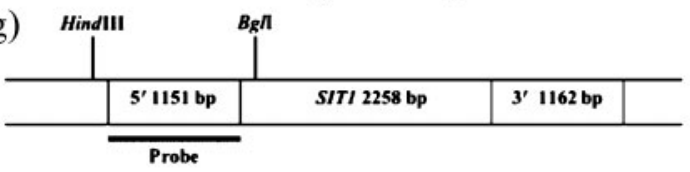

(h)

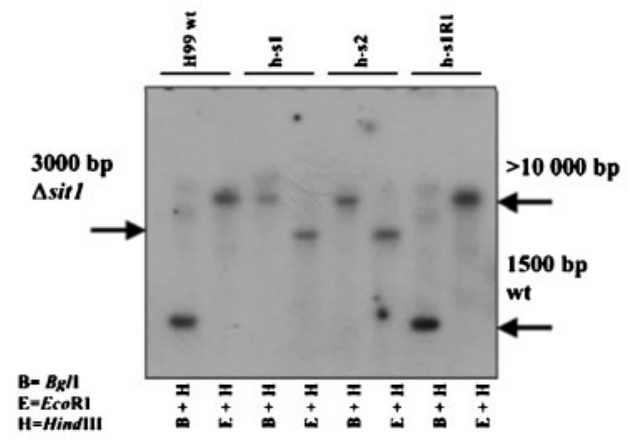

Fig. 2. Structure of SIT1 deletion constructs and confirmation of homologous replacements in strains B3501A and H99. (a) Restriction enzyme sites in the $\Delta$ sit 1 construct. (b) The corresponding sites in the SIT1 gene from strain B3501A. (c-e) Southern blots of genomic DNA digested with EcoRI/Ncol, Scal or Stul as indicated, and hybridized with a fragment of the SIT1 gene [labelled as probe in (a) and (b)]. (f) Bgll and Hindlll restriction enzyme sites in the $\Delta$ sit1 construct. (g) The corresponding sites in the S/T1 gene from strain H99. (h) Southern blot of genomic DNA digested with Bgll and Hindlll or EcoRI and Hindlll, and hybridized with the SIT1 probe indicated in $(f)$ and $(\mathrm{g})$.

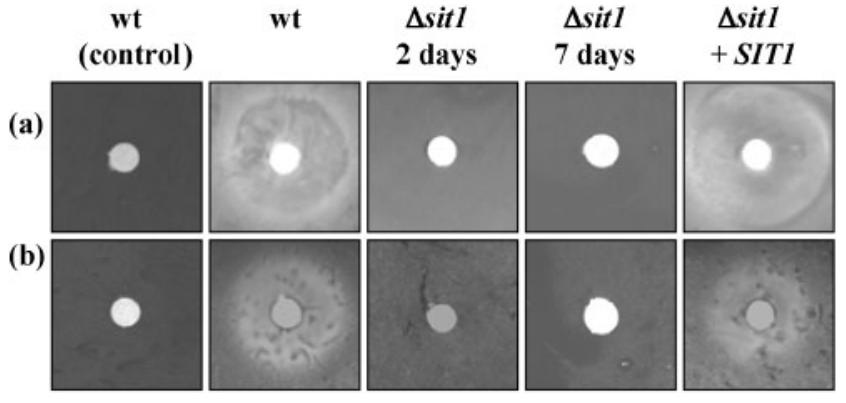

Fig. 3. sit 1 mutants are unable to acquire iron from a siderophore. Siderophore utilization was tested by spreading cells on LIM plates containing BPDA. A disk containing deferoxamine was placed in the centre of each plate, and the cultures were incubated for 2 or 7 days at $30^{\circ} \mathrm{C}$. (a) Strain B3501A; (b) strain $\mathrm{H} 99$. The assays were repeated several times.

indicates that SIT1 is not required for ferrichrome utilization, although it is not possible to rule it out as a substrate from this experiment.

The analysis of growth in liquid media revealed that loss of SIT1 greatly reduced growth of the mutants in LIM, and when siderophore was provided as the sole iron source (BPDA chelator + deferoxamine) (Fig. 4). None of the strains (wt or mutant) was able to grow in LIM with the BPDA chelator (data not shown), and all strains showed similar growth patterns in LIM $+\mathrm{Fe}$, although growth was slightly delayed for sit 1 mutants (wt levels were achieved by 36 h; Fig. 4). The wt H99 strain also showed reduced growth in LIM $\left(\mathrm{OD}_{600} \sim 5\right.$ at $\left.54 \mathrm{~h}\right)$ compared with that of strain B3501A $\left(\mathrm{OD}_{600} \sim 8\right.$ at $\left.54 \mathrm{~h}\right)$, suggesting that this strain may be more sensitive to low-iron conditions. Overall, these results indicate that Sit 1 plays a role in iron acquisition in a low-iron environment, and in the use of FOB as a sole iron source.

\section{The sit1 mutants exhibit altered melanin deposition and laccase activity}

Previous studies have indicated a potential connection between melanin and iron in C. neoformans (Polacheck et al., 1982; Jacobson \& Compton, 1996; Jacobson, 2000). Therefore, we tested the ability of the sit 1 mutants to produce melanin, and found enhanced melanization in the B3501A mutant grown on agar medium containing the substrate DOPA (Fig. 5a). In particular, the mutant produced melanin more rapidly, and the surface of the colony appeared rougher, with a higher sheen compared to that of the wt (Fig. 5a). In addition, we noted that B3501A wt cells were able to invade the agar, whereas the sit 1 mutant could not (data not shown). No obvious change in melanization was observed for the H99 sit1 mutants compared to that for the wt (Fig. 5a). We also tested a higher substrate concentration to determine if wt melanization would be enhanced to match the sit1 mutant phenotype 
(Fig. 5a). We found that a fourfold higher level of DOPA enhanced melanin formation in strain B3501A but not in H99, suggesting that substrate availability may have been a factor in the melanization difference between the B3501A sit1 mutant and the wt. We also found that $1.0 \%$ glucose could repress melanin production in all strains, indicating that the sit1 mutation did not affect the known negative regulatory influence of glucose (Fig. 5a) (Nurudeen \& Ahearn, 1979; Pukkila-Worley et al., 2005).
We looked more closely at melanin production by measuring laccase activity, and found slightly elevated levels in the sit1 mutants in both strain backgrounds (Fig. 5b). These results indicated that laccase activity was affected by the loss of SIT1 in each strain, even though no difference in melanization was noted for the sit1 mutant of strain H99 grown on solid medium. It is possible that the variation in laccase activity was the result of differences in metal availability to the enzyme between mutant and wt
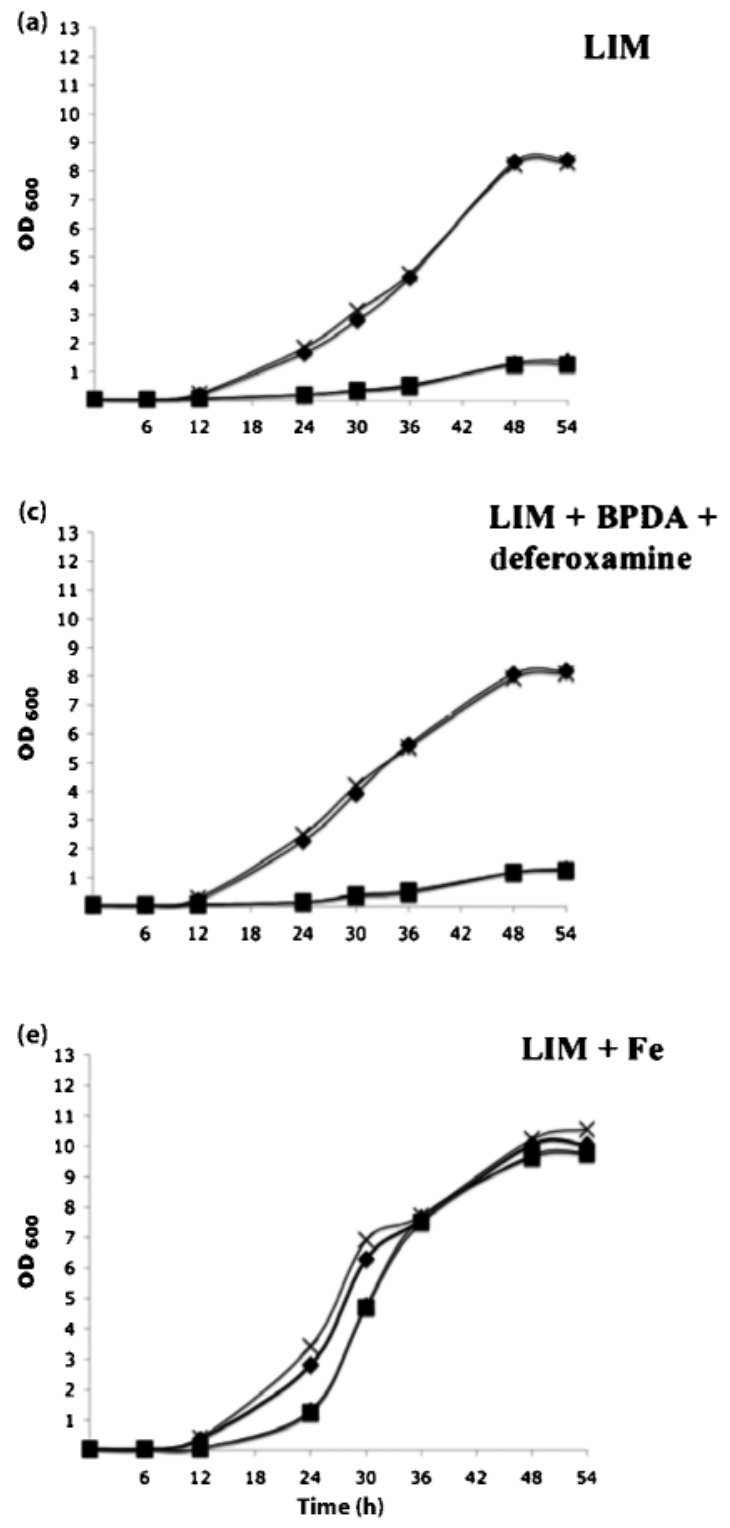

(b) 13

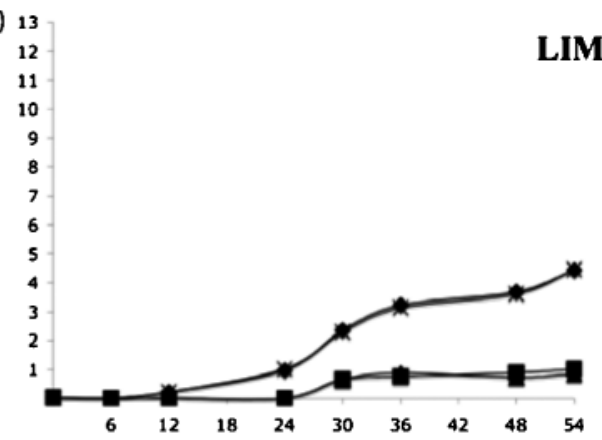

(d) 13

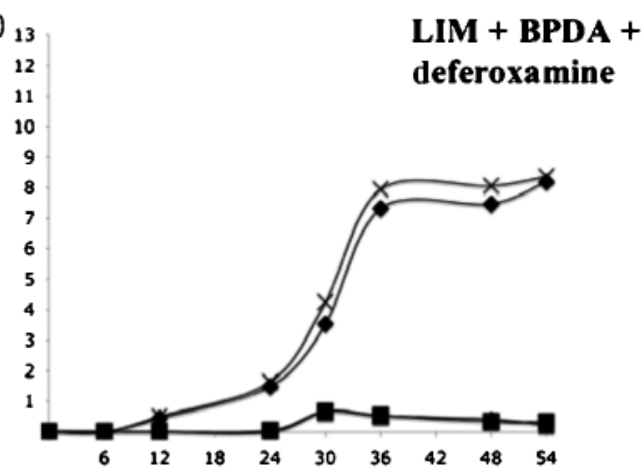

(f)

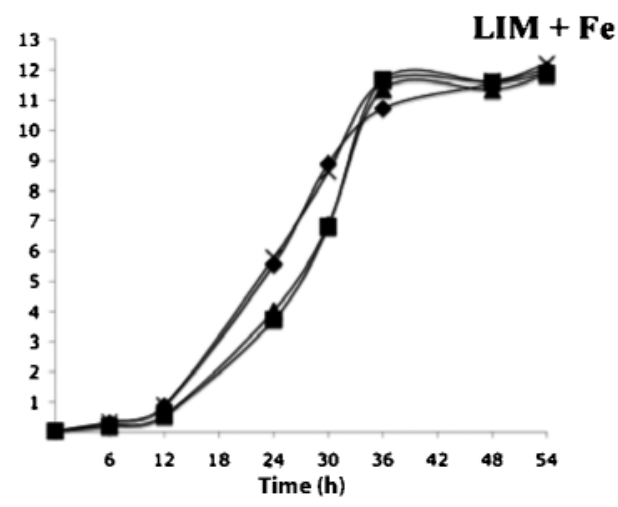

Fig. 4. Disruption of $S / T 1$ affects growth in $L I M$ and $L I M+B P D A+$ deferoxamine. Growth of cells in LIM (a), $\mathrm{LIM}+\mathrm{BPDA}$ + deferoxamine (c) and LIM + Fe (e) is shown for the serotype D strain B3501A (wt; $>$ ), two sit1::URA5 disruption mutants of B3501A (b-s10, $\mathbf{a}$; b-s42, $\mathbf{\Delta}$ ), and two reconstituted strains of B3501A (sit1::URA5+SIT1) (bs42R1 and b-s42R2, $\times)$. Comparison is also shown in $(b, d, f)$ with strain $\mathrm{H} 99(w t, \diamond)$, two sit1 : : NEO disruption mutants in H99 (h-s1, $\mathbf{\square} ; \mathrm{h}-\mathrm{s} 2, \boldsymbol{\Delta}$ ), and the reconstituted H99 mutant (sit1::NEO+SIT1) (h-s1R1, $\times$ ) grown in LIM (b), $\mathrm{LIM}+\mathrm{BPDA}+$ deferoxamine (d) and LIM +Fe (f). Graphs show the mean of three separate experiments. 
cells. That is, loss of SIT1 may have influenced metal homeostasis in the cells, resulting in a change in laccase activity due to metal loading on the copper-requiring enzyme. To test this hypothesis, we repeated the assays with cells incubated in the presence of added copper, and found that laccase activity was elevated in the wt and reconstituted strains, matching the level in the mutants (Fig. 5c). These results suggest that loss of SIT1 influences copper loading on laccase, perhaps through altered metal homeostasis and/or changes in laccase expression or localization (normally in the cell wall) between mutant and wt strains.

We also examined whether the changes in laccase activity could have been due in part to differences in transcript levels between mutant and wt cells. Real-time PCR was used to measure laccase (LAC1) transcript levels in wt, mutant and reconstituted cells grown in low-glucose medium, with or without the addition of iron or copper (see Methods). As shown in Fig. 5(d), no differences in $L A C 1$ transcript levels were found for the $\mathrm{H} 99$ strains grown under any conditions, or for the B3501A strains grown in medium without metal supplementation. However, higher transcript levels were found in the B3501A mutant grown in medium with iron or copper compared with those in the wt or reconstituted strains. These findings suggest that loss of SIT1 influences laccase expression at the transcript level in the serotype D strain, and that metal repletion is important for this effect.

\section{Loss of SIT1 in the serotype D background results in temperature sensitivity and altered cell wall structure}

We were intrigued by the idea that loss of SIT1 might influence the localization of laccase, as suggested by the influence of substrate concentration and metal availability described above. Given the location of laccase in the cell

(a)

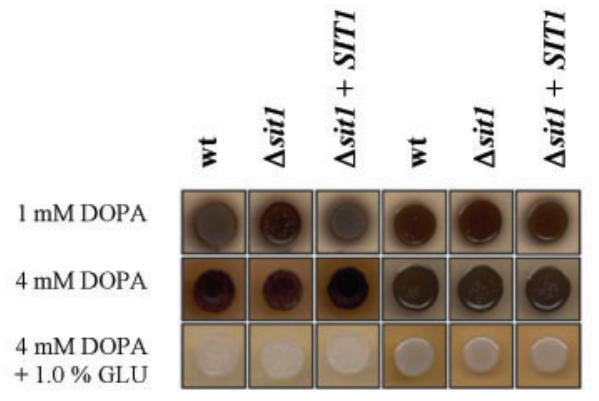

(b)

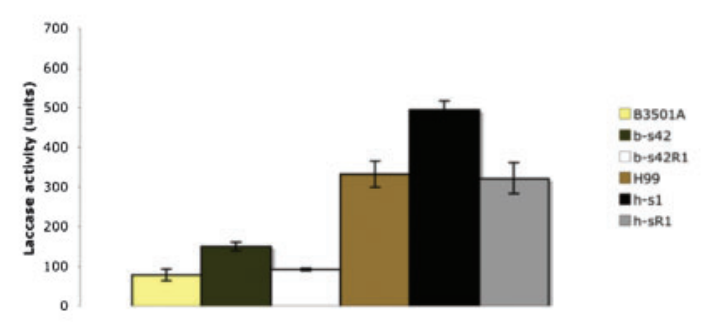

(c)

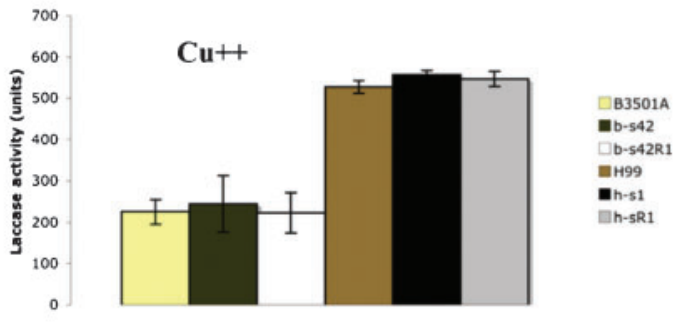

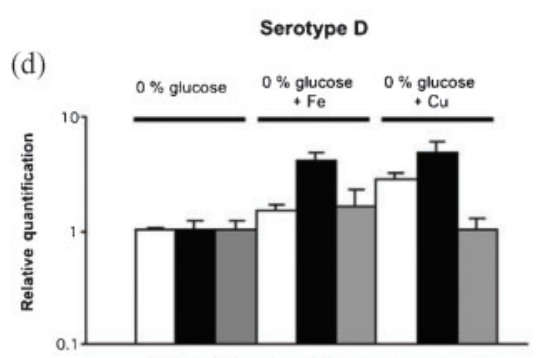

(I) wt; (I) $\Delta$ sitt; (I) $\Delta$ sit1 + SIT1

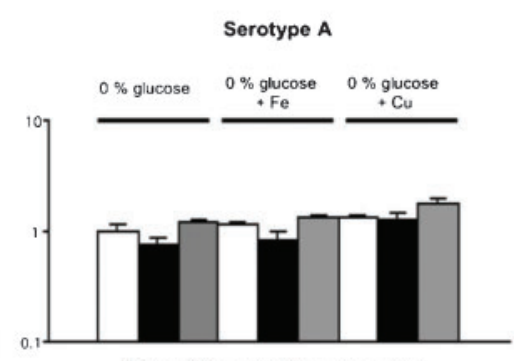

(I) wt; (I) $\Delta$ sit1; (I) $\Delta$ sit1 + SIT1
Fig. 5. Melanin production, laccase activity and LAC1 transcript levels in sit1 mutants. (a) To test for melanin production, $10 \mu \mathrm{l} \mathrm{cul-}$ tures of wt or mutant cells $\left(10^{7} \mathrm{ml}^{-1}\right)$ were spotted onto $0.1 \%$ glucose plates containing $1 \mathrm{mM}$ DOPA, $4 \mathrm{mM}$ DOPA or $4 \mathrm{mM}$ DOPA $+1.0 \%$ glucose. Plates were incubated for 2 days at $30^{\circ} \mathrm{C}$. (b, c) Laccase assays were performed for all strains with $10^{8}$ cells (see Methods) and for (c), the cells were grown in the presence of $100 \mu \mathrm{M}$ copper sulfate. (d) Relative quantification of LAC1 transcriptional levels ( $y$ axis) was performed as described in Methods. Strains of B3501A (Serotype D) and H99 (Serotype A) were used for the analysis, and the $L A C 1$ expression levels in the wt strain of each serotype were used as a calibrator. The results are from triplicate assays, and the error bars represent standard errors of the mean expression levels. 
$30^{\circ} \mathrm{C}$

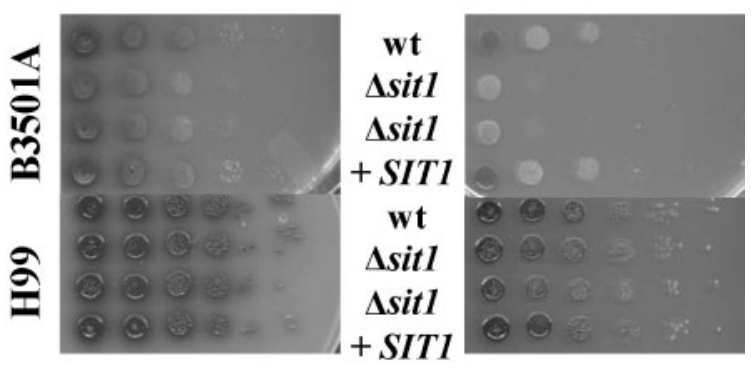

Fig. 6. Temperature sensitivity assays. To test for temperature sensitivity and cell wall integrity, serial dilutions of cells (from $10^{2}$ to $10^{7}$ c.f.u. $\mathrm{ml}^{-1}$ ) were spotted onto solid $0.1 \%$ glucose $+1 \mathrm{mM}$ DOPA medium, and plates were incubated for 2 days at 30 or $37^{\circ} \mathrm{C}$. The assays were repeated three times with similar results.

wall, we investigated whether the mutants showed differences in wall integrity. First, we tested growth in the presence of calcofluor white, SDS and Congo red on low-glucose or DOPA plates. Only slight sensitivity to these compounds was observed for the B3501A sit1 mutant compared with that for the wt, and no difference was noted for the H99 strains (data not shown). The cells were also tested for temperature sensitivity (a phenotype associated with cell wall integrity) by spotting serial dilutions of cells on DOPA plates (Fig. 6). The sit1 mutants showed slightly less growth than wt at $30^{\circ} \mathrm{C}$, and reduced growth at $37^{\circ} \mathrm{C}$ for the
B3501A mutant (Fig. 6). The temperature sensitivity was particularly apparent in the B3501A background, and no difference was noted for the H99 strains (Fig. 6). Similar results were obtained in medium without DOPA (data not shown). The temperature sensitivity of the sit 1 mutant in the B3501A background was confirmed in growth assays in liquid LGA medium (data not shown).

The changes in melanin production and the temperature sensitivity prompted a closer examination of the cell wall of the sit1 mutants. We employed TEM of melanized cells (grown for 4 days on DOPA plates) and non-melanized cells (grown for 4 days on LGA plates), and observed a difference in cell wall organization between the sit1 mutants, the reconstituted strains and the wt cells (Fig. 7). The cell walls of the wt and reconstituted cells contained distinct and dense concentric rings, and ordered polysaccharide fibrils, consistent with the observations of Eisenman et al. (2005). In contrast, the mutant walls appeared to be less dense, and they varied in thickness, with less ordered fibrils. The mutant cells in the B3501A strain were also easily distorted by the TEM processing (Fig. 7). For example, among a sample of 40 cells examined for each strain, $89 \%$ of sit1 mutant cells from strain B3501A were distorted (not spherical) versus $7.4 \%$ of the wt cells (data not shown). An independent preparation for TEM with prolonged dehydration steps reduced the distortion in the mutant cells, but the defect was still more apparent in the mutant cells (data not shown). These results suggest that loss of sit1 caused an altered organization of the cell wall in strain B3501A. Although the mutant cells in the H99 background (a)
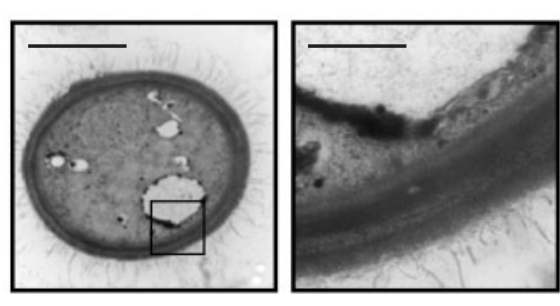

(b)

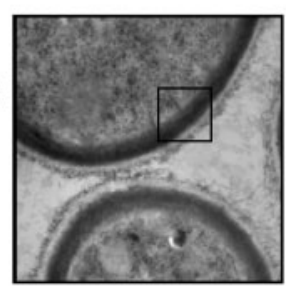

$\times 30000$

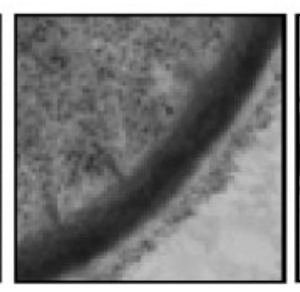

$\times 150000$

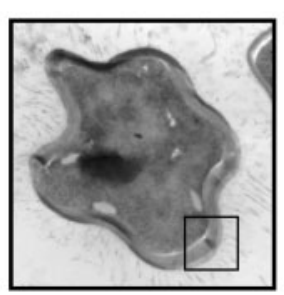

Asit1
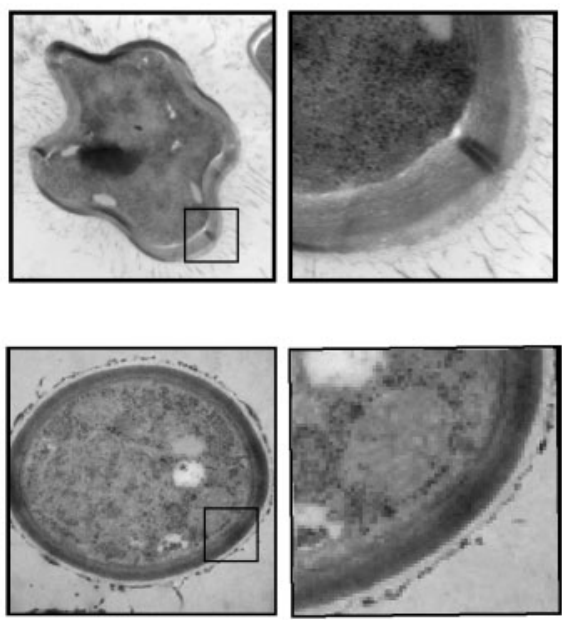

$\times 30000$

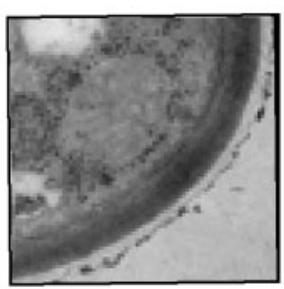

$\times 150000$
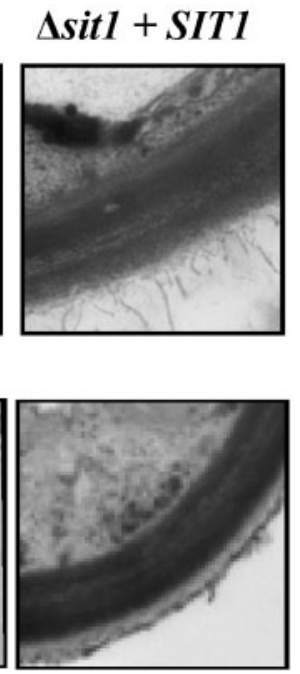

$\times 150000$

Fig. 7. TEM of melanized cells for wt and sit1 mutants. Two magnifications of the same cell are shown for the mutant and parental strains, and the reconstituted strains are shown at the higher magnification. The images show a cross section of the cell wall, cytoplasm and polysaccharide capsule for strains B3501A (a) and H99 (b). Approximately 50 cells were examined for each strain, and representative images are shown. Bars: $\times 30000,4 \mu \mathrm{m} ; \times 150000,0.8 \mu \mathrm{m}$. 
appeared to have a less dense wall, they did not show the same distortion upon processing; this is consistent with the lack of changes in melanization, and temperature and cell wall sensitivity, in the H99 mutants. Finally, the differences in the cell wall noted for the sit 1 mutants were apparent by TEM even in the non-melanized cells grown on LGA plates (data not shown). Taken as a whole, these results suggest that cell wall changes were present in the sit1 mutants, and that these were particularly apparent in the serotype D strain B3501A.

\section{Protein kinase A (PKA) influences SIT1 transcript levels}

In $S$. cerevisiae, the cAMP pathway and the TPK2 gene encoding a catalytic subunit of PKA have been implicated in the negative regulation of iron-uptake genes, including ARN3/SIT1 (Robertson et al., 2000). We were therefore interested in the effect of the cAMP pathway on siderophore utilization in C. neoformans, especially given the influence of the pathway on melanin. We obtained mutants defective in the genes encoding the catalytic subunits of PKA in both serotype A and serotype D strains (D'Souza et al., 2001; Hicks et al., 2004), and used RT-PCR to measure SIT1 transcript levels. We found that a defect in pka1, but not pka2, resulted in elevated SIT1 transcripts in strain JEC21 (a close relative of $\mathrm{B} 3501 \mathrm{~A})$, while both the pka1 and the pka2 mutants showed elevated transcripts in strain H99 (Fig. 8). These results suggest that similarities exist between $S$. cerevisiae and C. neoformans in the regulation of siderophore transport expression by PKA. The possible connection between siderophore utilization (perhaps involving SIT1) and the cAMP pathway prompted us to examine the sit 1 mutants for defects in other traits associated with cAMP signalling, including capsule formation (D'Souza et al., 2001) and mating (Alspaugh et al., 2002). No difference in capsule size or induction was noted between any of the wt or mutant cells grown in LIM and LIM + Fe conditions, suggesting that SIT1 is not required for this trait (data not shown). Similarly, mating tests with serotype A or D MATa strains and the corresponding MAT $\alpha$ sit 1 mutants indicated that no unilateral mating defect was caused by the loss of SIT1 (data not shown).

\section{SIT1 is not required for virulence in a murine model of cryptococcosis}

We next tested the virulence of the sit 1 mutant, because of the importance of iron acquisition during infection, and the fact that the mammalian host environment is low in free iron. Initially, we used strain B3501A and its sit 1 mutants in a mouse inhalation model (DBA1 mice), but differences in virulence were not observed (data not shown). However, B3501A strains were generally only weakly virulent in our assays. Therefore, virulence was also tested for the H99 strains using the murine model. In the first trial, A/Jcr mice were infected intranasally with an inoculum of $5 \times 10^{4}$ cells per mouse, but no differences in survival $(\sim 20 \pm 2$ days) were noted between these strains (data not shown). Fungal cell counts from brain and lung tissue were performed for two mice for each of the wt and the mutant strains, and one mouse for the sit1 + SIT1 reconstituted strain. Cell counts were equivalent for the brains $\left[\sim 10^{5}\right.$ cells $\left.(\mathrm{g} \text { tissue })^{-1}\right]$ and lungs $\left[\sim 10^{6}\right.$ cells $\left.(\mathrm{g} \text { tissue })^{-1}\right]$ for all of the infections, further indicating that SIT1 is not necessary for extrapulmonary dissemination in this model. The sit1 mutant cells isolated from the brain were retested in the siderophore utilization assay to confirm that the strain was unable to use deferoxamine (data not shown). In a second trial, a 10-fold lower inoculum of $5 \times 10^{3}$ cells was used with five mice per strain. Again, there was no difference in virulence between sit1 mutants and wt strains, although the mice survived slightly longer with the lower inoculum (26-27 days; data not shown). Overall, these results indicated that SIT1 is not required for virulence in this model.

\section{DISCUSSION}

\section{The role of SIT1 in iron acquisition}

The acquisition of iron is essential for the proliferation of pathogens in the host environment, and siderophores are known to be important facilitators of iron uptake in several bacterial pathogens (Ratledge \& Dover, 2000). Siderophore production by $C$. neoformans has not been detected (Jacobson \& Petro, 1987), but the fungus may use transporters to capitalize on siderophores produced by nutritional competitors in the environment. We therefore

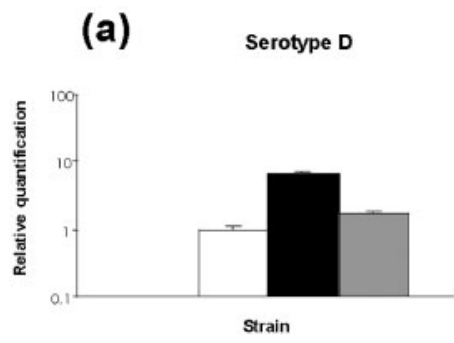

(b)

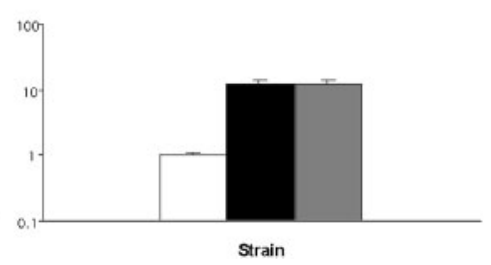

Fig. 8. Influence of cAMP signalling mutants on SIT1 transcript levels. ( $a, b)$ Relative quantification of SIT1 transcriptional levels ( $y$ axis) was accomplished as described in Methods. Strains of JEC21 (Serotype D) and H99 backgrounds (Serotype A) were used for analysis, and the SIT1 expression levels in the wt strain of each serotype were used as a calibrator. The results are from triplicate assays, and the error bars represent standard errors of the mean expression levels. White bars, wt; black bars, $\Delta p k a 1$; grey bars, $\Delta p k a 2$. 
characterized the putative siderophore transporter gene SIT1, and found that the gene is essential for the use of FOB, but not ferrichrome, as a sole source of iron. In addition, the lack of growth of sit1 mutants in LIM may indicate a connection to components of the high- or low-affinity uptake systems, such as the iron permease FTR1 or the multicopper oxidase FET3 (Lian et al., 2005). With regard to the use of FOB, our observations suggest that none of the other candidate genes for siderophore transporters is functionally redundant with SIT1 under the conditions tested. However, the interpretation of redundancy can be complicated, as demonstrated by attempts to examine the specificity of the four siderophore transporters in $S$. cerevisiae (discussed by Kosman, 2003; Lesuisse et al., 2001; Yun et al., 2000a, b). In brief, it appears that there is considerable redundancy among the four transporters, although there is some specificity of Sit 1 for FOB and Taf1/Arn2 for triacylfusarinine. In addition, variation is observed when the influence of transporter deletions is assessed in different strain backgrounds or laboratories. This suggests that transporter specificity may be a multigenic trait (Kosman, 2003). Given the variation that we have already observed between serotype A and D strains, the evaluation of specificity for Sit1 in C. neoformans and for the other candidates for siderophore transporters will likely require careful analysis of single and multiple deletion mutants in a single strain background.

\section{Connections between Sit1, melanin, cell wall and signalling pathways}

Loss of Sit1 in the B3501A background resulted in enhanced melanin formation, and increased laccase activity was seen for the sit1 mutants in both B3501A and H99. Our results suggest that loss of SIT1 results in increased laccase activity by multiple mechanisms, including transcription of the $L A C 1$ gene, access of the enzyme to substrate (perhaps due to altered localization or cell wall structure), and copper loading of the enzyme. $L A C 1$ transcription is known to be responsive to iron and copper (Zhu et al., 2003), and our observations are consistent with a role for Sit1 in metal homeostasis. Additionally, Walton et al. (2005) have demonstrated the importance of copper and iron homeostasis for melanization, through an insertional mutagenesis approach to identify mutants with reduced melanin production. Specifically, they have identified mutations in C. neoformans homologues of the copper transporter Ccc2 and the copper chaperone Atxl, along with a chitin synthase gene and two transcriptional regulators. The mutants defective in CCC2 or ATX1 fail to grow on medium with an iron chelator, perhaps due to a role in providing copper to iron-uptake functions, such as the Fet3 multicopper oxidase. The role of the chitin synthase gene is interesting and provides a link between cell wall defects and laccase localization. Mutants with a defect in the chitin synthase gene give a 'leaky' melanin phenotype, likely due to a failure of laccase retention in the wall (Walton et al., 2005).
Our TEM observations suggest a reduced density for the cell wall in the sit1 mutants in both strain backgrounds. A recent description of the microstructure of the wall of $C$. neoformans has revealed that melanin is present in concentric layers of spherical granular particles with a diameter of 40-130 nm (Eisenman et al., 2005). In light of this description, it is possible that SIT1 contributes to laccase localization and therefore to melanin deposition in the wall. However, changes in the cell wall were noted even in the absence of the melanin substrate, and were also observed in strain H99, in which loss of SIT1 did not noticeably affect melanin production (although laccase activity was slightly increased). Therefore, it seems that melanin localization is not the sole cause of the cell wall changes. Although further analysis is needed, it is possible that Sit1 may play a role in the exocytosis or endocytosis of components such as laccase, or factors required for laccase activity, to the cell wall, particularly in the serotype D strain. Connections between siderophore transporters, trafficking and the cell wall have been established in S. cerevisiae. For example, Arn1 cycles from the plasma membrane to endosomes, depending on the concentration of siderophore (Kim et al., 2002). Additionally, Arn3 has been shown recently to interact with a cell wall protein, Sed1, and a role for the cell wall Fit proteins in siderophore transport has been established in yeast (Park et al., 2005; Protchenko et al., 2001).

Our observations on the influence of copper addition on $L A C 1$ transcription and laccase activity in the sit1 mutants are similar to the results reported by Zhu et al. (2003). They have found that a defect in vacuolar acidification, due to deletion of the VPH1 gene (encoding a vacuolar $\mathrm{H}^{+}$ATPase), leads to a defect in copper assembly into laccase. The mutants properly translate, secrete and localize laccase, but the enzyme is inactive. Copper addition restores laccase activity and results in increased transcription of the $L A C 1$ gene. They discuss the possibility that insertion of copper into laccase, perhaps in the outer Golgi network where the ATPase is located, might require acidification. The similarities with the influence of Sit1 on laccase support the hypothesis that Sit1 is important for metal homeostasis, perhaps through a role in trafficking or storing iron.

The influence of Sit1 on melanin production suggests possible connections with known regulators of this process in C. neoformans. For example, the PKC1/MAPK pathway has been recently implicated in melanization because the loss of the $\mathrm{C} 1$ domain (for diacylglycerol binding) of PKC1 leads to loss of laccase activity and melanin production (Heung et al., 2005). The C1 mutants display a similar phenotype to the serotype D sit1 mutant, in that they have disorganized melanization (due to displacement of laccase) and reduced cell wall integrity. The cAMP pathway also controls laccase expression (D'Souza et al., 2001; PukkilaWorley et al., 2005), and we found that mutations in the genes encoding the catalytic subunits of PKA influenced SIT1 transcript levels. These results suggest that, as in $S$. cerevisiae, PKA negatively regulates some iron-uptake 
functions (Robertson et al., 2000). In this regard, SIT1 will be a useful target gene for future analysis of gene expression, including transcription factor characterization, because of the co-regulation of transcript levels by the cAMP pathway and iron.

\section{SIT1 and fungal infection}

We found that SIT1 was not required for virulence in a murine inhalation model of cryptococcosis, even though the sit1 mutants showed poor growth in LIM. We were prompted to test the virulence of the sit1 mutants because of observations in bacterial (Ratledge \& Dover, 2000) and other fungal pathogens. Specifically, a siderophore transporter is not required for the virulence of $C$. albicans in a murine systemic infection model, but is required for epithelial cell invasion (Heymann et al., 2002). In contrast, the high-affinity iron permease Ftr1 is required for systemic infection with C. albicans (Ramanan \& Wang, 2000). Iron removal from holotransferrin may be siderophore-mediated in A. fumigatus, and the SidA gene that encodes an ornithine monooxygenase involved in siderophore synthesis is essential for virulence of A. fumigatus (Hissen et al., 2004, 2005; Schrettl et al., 2004). However, reductive iron assimilation by the high-affinity uptake system through FtrA is not required for virulence. There are a number of explanations for why SIT1 may not be required for virulence in C. neoformans. First, C. neoformans does not appear to produce its own siderophores (Jacobson \& Petro, 1987), so it is unclear whether a transporter would be useful during infection. Second, even if siderophores were available in the host, other siderophore transporters might contribute to iron acquisition in place of Sit1. That is, there are issues of specificity and redundancy to consider, and we have so far only found that Sit1 can promote use of the bacterial siderophore FOB (not expected to be present in the host). Finally, it has recently been shown in C. albicans that the reductive iron-uptake system is responsible for the acquisition of iron that is tightly bound to ferritin (Knight et al., 2005). If the same were true for $C$. neoformans, then the functional FTR1/FET3 system in the sit1 mutants might effectively acquire iron from ferritin in the mouse. Generally, it is possible that sufficient iron is available in vivo to allow survival of the fungus by other iron-uptake mechanisms, even in the absence of Sit1. An exploration of the role of other uptake systems (e.g. Ftr1/Fet3) in virulence is currently under way.

\section{ACKNOWLEDGEMENTS}

We thank Barbara Steen for help with the RNA analysis, Joseph Heitman for vectors and strains, and Cletus D'Souza for critical comments on the manuscript. We thank Elaine Humphrey, Kim Rensing, Garnet Martens and Derrick Horne at the University of British Columbia BioImaging Facility for technical assistance. We also thank Lacey Samuels for helpful discussion and Brian Wickes for communicating results prior to publication. This work was supported by the Canadian Institutes for Health Research (CIHR) and the National Institute of Allergy and Infectious Disease (R01 AI053721).

\section{REFERENCES}

Alspaugh, J. A., Perfect, J. R. \& Heitman, J. (1997). Cryptococcus neoformans mating and virulence are regulated by the G-protein alpha subunit GPA1 and cAMP. Genes Dev 11, 3206-3217.

Alspaugh, J. A., Pukkila-Worley, R., Harashima, T., Cavallo, L. M., Funnell, D., Cox, G. M., Perfect, J. R., Kronstad, J. W. \& Heitman, J. (2002). Adenylyl cyclase functions downstream of the $G$ alpha protein Gpal and controls mating and pathogenicity of Cryptococcus neoformans. Eukaryot Cell 1, 75-84.

Altschul, S. F., Gish, W., Miller, W., Myers, E. W. \& Lipman, D. J. (1990). Basic local alignment search tool. J Mol Biol 215, 403-410.

Ardon, O., Bussey, H., Philpott, C., Ward, D. M., Davis-Kaplan, S., Verroneau, S., Jiang, B. \& Kaplan, J. (2001). Identification of a Candida albicans ferrichrome transporter and its characterization by expression in Saccharomyces cerevisiae. J Biol Chem 276, 43049-43055.

Barasch, J. \& Mori, K. (2004). Cell biology: iron thievery. Nature 432, 811-813.

Barchiesi, F., Cogliati, M., Esposto, M. C., Spreghini, E., Schimizzi, A. M., Wickes, B. L., Scalise, G. \& Viviani, M. A. (2005). Comparative analysis of pathogenicity of Cryptococcus neoformans serotypes A, D and $\mathrm{AD}$ in murine cryptococcosis. J Infect 51, 10-16.

Bose, I., Reese, A. J., Ory, J. J., Janbon, G. \& Doering, T. L. (2003). A yeast under cover: the capsule of Cryptococcus neoformans. Eukaryot Cell 2, 655-663.

Casadevall, A. \& Perfect, J. R. (1998). Cryptococcus neoformans. Washington, DC: American Society for Microbiology.

Cowart, R. E., Singleton, F. L. \& Hind, J. S. (1993). A comparison of bathophenanthrolinedisulfonic acid and ferrozine as chelators of iron(II) in reduction reactions. Anal Biochem 211, 151-155.

Davidson, R. C., Blankenship, J. R., Kraus, P. R., de Jesus Berrios, M., Hull, C. M., D'Souza, C., Wang, P. \& Heitman, J. (2002). A PCRbased strategy to generate integrative targeting alleles with large regions of homology. Microbiology 148, 2607-2615.

D’Souza, C. A., Alspaugh, J. A., Yue, C., Harashima, T., Cox, G. M., Perfect, J. R. \& Heitman, J. (2001). Cyclic AMP-dependent protein kinase controls virulence of the fungal pathogen Cryptococcus neoformans. Mol Cell Biol 21, 3179-3191.

Eisenman, H. C., Nosanchuk, J. D., Webber, J. B., Emerson, R. J., Camesano, T. A. \& Casadevall, A. (2005). Microstructure of cell wall-associated melanin in the human pathogenic fungus Cryptococcus neoformans. Biochemistry 44, 3683-3693.

Gomez, B. L. \& Nosanchuk, J. D. (2003). Melanin and fungi. Curr Opin Infect Dis 16, 91-96.

Haas, H. (2003). Molecular genetics of fungal siderophore biosynthesis and uptake: the role of siderophore in iron uptake and storage. Appl Microbiol Biotechnol 62, 316-330.

Heung, L. J., Kaiser, A. E., Luberto, C. \& Del Poeta, M. (2005). The role and mechanism of diacylglycerol-protein kinase $\mathrm{C} 1$ signaling in melanogenesis by Cryptococcus neoformans. J Biol Chem 280, 28547-28555.

Heymann, P., Gerads, M., Schaller, M., Dromer, F., Winkelmann, G. \& Ernst, J. F. (2002). The siderophore iron transporter of Candida albicans (Sitlp/Arn1p) mediates uptake of ferrichrome-type siderophores and is required for epithelial invasion. Infect Immun 70, 5246-5255.

Hicks, J. K., D'Souza, C. A., Cox, G. M. \& Heitman, J. (2004). Cyclic AMP-dependent protein kinase catalytic subunits have divergent roles in virulence factor prodution in two varieties of the fungal pathogen Cryptococcus neoformans. Eukaryot Cell 3, 14-26. 
Hissen, A. H., Chow, J. M., Pinto, L. J. \& Moore, M. M. (2004). Survival of Aspergillus fumigatus in serum involves removal of iron from transferrin: the role of siderophores. Infect Immun 72, $1402-1408$

Hissen, A. H., Wan, A. N., Warwas, M. L., Pinto, L. J. \& Moore, M. M. (2005). The Aspergillus fumigatus siderophore biosynthetic gene sidA, encoding L-ornithine N5-oxygenase, is required for virulence. Infect Immun 73, 5493-5503.

Hu, C. J., Bai, C., Zheng, X. D., Wang, Y. M. \& Wang, Y. (2002). Characterization and functional analysis of the siderophore-Fe transporter CaArnlp in Candida albicans. J Biol Chem 277, 30598-30605.

Jacobson, E. S. (2000). Pathogenic roles for fungal melanins. Clin Microbiol Rev 13, 708-717.

Jacobson, E. S. \& Compton, G. M. (1996). Discordant regulation of phenoloxidase and capsular polysaccharide in Cryptococcus neoformans. J Med Vet Mycol 34, 289-291.

Jacobson, E. S. \& Petro, M. J. (1987). Extracellular iron chelation in Cryptococcus neoformans. J Med Vet Mycol 25, 415-418.

Jacobson, E. S., Goodner, A. P. \& Nyhus, K. J. (1998). Ferrous iron uptake in Cryptococcus neoformans. Infect Immun 66, 4169-4175.

Janbon, G. (2004). Cryptococcus neoformans capsule biosynthesis and regulation. FEMS Yeast Res 4, 765-771.

Kim, Y., Yun, C.-W. \& Philpott, C. C. (2002). Ferrichrome induces endosome to plasma membrane cycling of the ferrichrome tranporter, Arn1p, in Saccharomyces cerevisiae. EMBO J 21, 3632-3642.

Knight, S. A., Vilaire, G., Lesuisse, E. \& Dancis, A. (2005). Iron acquisition from transferrin by Candida albicans depends on the reductive pathway. Infect Immun 73, 5482-5492.

Kosman, D. J. (2003). Molecular mechanisms of iron uptake in fungi. Mol Microbiol 47, 1185-1197.

Lesuisse, E., Simon-Casteras, M. \& Labbe, P. (1998). Siderophoremediated iron uptake in Saccharomyces cerevisiae: the SIT1 gene encodes a ferrioxamine $\mathrm{B}$ permease that belongs to the major facilitator superfamily. Microbiology 144, 3455-3462.

Lesuisse, E., Blaiseau, P. L., Dancis, A. \& Camadro, J. M. (2001). Siderophore uptake and use by the yeast Saccharomyces cerevisiae. Microbiology 147, 289-298.

Lian, T. S., Simmer, M. I., D'Souza, C. A., Steen, B. R., Zuyderduyn, S. D., Jones, S. J., Marra, M. A. \& Kronstad, J. W. (2005). Ironregulated transcription and capsule formation in the fungal pathogen Cryptococcus neoformans. Mol Microbiol 55, 1452-1472.

Liu, L., Tewari, R. P. \& Williamson, P. R. (1999). Laccase protects Cryptococcus neoformans from antifungal activity of alveolar macrophages. Infect Immun 11, 6034-6039.

Livak, K. J. \& Schmittgen, T. D. (2001). Analysis of relative gene expression data using real-time quantitative PCR and the $2(-$ delta delta C(T)) method. Methods 25, 402-408.

Loftus, B. J., Fung, E., Roncaglia, P., Rowley, D., Amedeo, P., Bruno, D., Vamathevan, J., Miranda, M., Anderson, I. J. \& other authors (2005). The genome of the basidiomycetous yeast and human pathogen Cryptococcus neoformans. Science 307, 1321-1324.

Noverr, M. C., Williamson, P. R., Fajardo, R. S. \& Huffnagle, G. B. (2004). CNLAC1 is required for extrapulmonary dissemination of Cryptococcus neoformans but not pulmonary persistence. Infect Immun 3, 1693-1699.

Nurudeen, T. A. \& Ahearn, D. G. (1979). Regulation of melanin production by Cryptococcus neoformans. J Clin Microbiol 10, 724-729.

Nyhus, K. J. \& Jacobson, E. S. (1999). Genetic and physiologic characterization of ferric/cupric reductase constitutive mutants of Cryptococcus neoformans. Infect Immun 5, 2357-2365.
Nyhus, K. J., Wilborn, A. T. \& Jacobson, E. S. (1997). Ferric iron reduction by Cryptococcus neoformans. Infect Immun 65, 434-438.

Park, Y. S., Jeong, H. S., Sung, H. C. \& Yun, C. W. (2005). Sed1p interacts with Arn3p physically and mediates ferrioxamine B uptake in Saccharomyces cerevisiae. Curr Genet 47, 150-155.

Perfect, J. R. (2005). Cryptococcus neoformans: a sugar-coated killer with designer genes. FEMS Immunol Med Microbiol 45, 395-404.

Polacheck, I., Hearing, V. J. \& Kwon-Chung, K. J. (1982). Biochemical studies of phenoloxidase and utilization of catecholamines in Cryptococcus neoformans. J Bacteriol 150, 1212-1220.

Protchenko, O., Ferea, T., Rashford, J., Tiedeman, J., Brown, P. O., Botstein, D. \& Philpott, C. C. (2001). Three cell wall mannoproteins facilitate the uptake of iron in Saccharomyces cerevisiae. J Biol Chem 276, 49244-49250.

Pukkila-Worley, R., Gerrald, Q. D., Kraus, P. R., Boily, M. J., Davis, M. J., Giles, S. S., Cox, G. M., Heitman, J. \& Alspaugh, J. A. (2005). Transcriptional network of multiple capsule and melanin genes governed by the Cryptococcus neoformans cyclic AMP cascade. Eukaryot Cell 4, 190-201.

Ramanan, N. \& Wang, Y. (2000). A high-affinity iron permease essential for Candida albicans virulence. Science 288, 1062-1064.

Ratledge, C. \& Dover, L. G. (2000). Iron metabolism in pathogenic bacteria. Annu Rev Microbiol 54, 881-941.

Robertson, L. S., Causton, H. C., Young, R. A. \& Fink, G. R. (2000). The yeast A kinases differentially regulate iron uptake and respiratory function. Proc Natl Acad Sci U S A 97, 5984-5988.

Salas, S. D., Bennett, J. E., Kwon-Chung, K. J., Perfect, J. R. \& Williamson, P. R. (1996). Effect of the laccase gene CNLAC1, on virulence of Cryptococcus neoformans. J Exp Med 184, 377-386.

Sambrook, J., Fritsch, E. F. \& Maniatis, T. (1989). Molecular Cloning: a Laboratory Manual, 2nd edn. Cold Spring Harbor, NY: Cold Spring Harbor Laboratory.

Schrettl, M., Bignell, E., Kragl, C., Joechl, C., Rogers, T., Arst, H. N., Jr, Haynes, K. \& Haas, H. (2004). Siderophore biosynthesis but not reductive iron assimilation is essential for Aspergillus fumigatus virulence. J Exp Med 200, 1213-1219.

Stearman, R., Yuan, D. S., Yamaguchi-Iwai, Y., Klausner, R. D. \& Dancis, A. (1996). A permease-oxidase complex involved in highaffinity iron uptake in yeast. Science 271, 1552-1557.

Toffaletti, D. L., Rude, T. H., Johnston, S. A., Durack, D. T. \& Perfect, J. R. (1993). Gene transfer in Cryptococcus neoformans by use of biolistic delivery of DNA. J Bacteriol 175, 1405-1411.

Varma, A., Edman, J. C. \& Kwon-Chung, K. J. (1992). Molecular and genetic analysis of URA5 transformants of Cryptococcus neoformans. Infect Immun 60, 1101-1108.

Vartivarian, S. E., Anaissie, E. J., Cowart, R. E., Sprigg, H. A., Tingler, M. J. \& Jacobson, E. S. (1993). Regulation of cryptococcal capsular polysaccharide by iron. J Infect Dis 167, 186-190.

Walton, F. J., Idnurm, A. \& Heitman, J. (2005). Novel gene functions required for melanization of the human pathogen Cryptococcus neoformans. Mol Microbiol 57, 1381-1396.

Williamson, P. R. (1997). Laccase and melanin in the pathogensis of Cryptococcus neoformans. Front Biosci 1, 99-107.

Yu, J. H., Hamari, Z., Han, K. H., Seo, J. A., Reyes-Dominguez, Y. \& Scazzocchio, C. (2004). Double-joint PCR: a PCR-based molecular tool for gene manipulations in filamentous fungi. Fungal Genet Biol 41, 973-981.

Yun, C.-W., Ferea, T., Rashford, J., Ardon, O., Brown, P. O., Botstein, D., Kaplan, J. \& Philpott, C. C. (2000a). Desferrioxamine-mediated iron uptake in Saccharomyces cerevisiae. Evidence for two pathways of iron uptake. J Biol Chem 275, 10709-10715. 
Yun, C.-W., Tiedeman, J., Moore, R. E. \& Philpott, C. C. (2000b). Siderophore-iron uptake in Saccharomyces cerevisiae. Identification of ferrichrome and fusarinine transporters. J Biol Chem 275, 16354-16359.

Zaragoza, O., Fries, B. C. \& Casadevall, A. (2003). Induction of capsule growth in Cryptococcus neoformans by mammalian serum and $\mathrm{CO}_{2}$. Infect Immun 71, 6155-6164.

Zhu, X. \& Williamson, P. R. (2004). Role of laccase in the biology and virulence of Cryptococcus neoformans. FEMS Yeast Res 5, 1-10.
Zhu, X., Gibbons, J., Garcia-Rivera, J., Casadevall, A. \& Williamson, P. R. (2001). Laccase of Cryptococcus neoformans is a cell wallassociated virulence factor. Infect Immun 69, 5589-5596.

Zhu, X., Gibbons, J., Zhang, S. \& Williamson, P. R. (2003). Coppermediated reversal of defective laccase in a $\Delta v p h 1$ avirulent mutant of Cryptococcus neoformans. Mol Microbiol 47, 1007-1014.

Edited by: N. L. Glass 